\title{
A new high protein-to-energy enteral formula with a whey protein hydrolysate to achieve protein targets in critically ill patients: a prospective observational tolerability study
}

\author{
Franziska Tedeschi-Jockers ${ }^{1}$, Simona Reinhold ${ }^{1}$, Alexa Hollinger $\mathbb{D}^{1 凶}{ }^{凶}$, Daniel Tuchscherer ${ }^{1}$, Caroline Kiss $\mathbb{D}^{2}$, Lukas Gantner ${ }^{1}$,
} Katrin Ledergerber ${ }^{1}$, Sibylle Zimmermann ${ }^{1}$, Jonas Scheuzger ${ }^{1}$, Jan Huber ${ }^{1}$ and Martin Siegemund (D) ${ }^{1}$

(c) The Author(s) 2021

\begin{abstract}
OBJECTIVES: Current guidelines and expert recommendations stress the need to implement enteral feeds with a higher protein-toenergy ratio to meet protein requirements as recommended while avoiding gastrointestinal side effects and energy overfeeding in ICU patients.

MATERIALS AND METHODS: Prospective tolerability study in 18 critically ill patients with a high protein formula (high protein-toenergy (HP:E) formula = Fresubin ${ }^{\circledR}$ Intensive; HPG) compared to a contemporary matched conventional therapy group (CTG). The primary outcome was Gl intolerance defined as $\geq 300 \mathrm{ml}$ daily gastric residual volume (GRV), vomiting, or diarrhea on days 1 and 2 . Secondary outcomes were the percentage of patients reaching their protein target on day 4 and overall protein intake.

RESULTS: Groups were comparable regarding demographic characteristics, disease severity, organ failures, mechanical ventilation, and NUTRIC score at baseline. Eighteen patients completed the 4-day feeding period. The number of events of GRV of $\geq 300 \mathrm{ml} / \mathrm{day}$ was equal in both groups (33.3\%). The incidence of diarrhea and vomiting was low in the HPG (two patients concerned). EN did not need to be discontinued due to intolerance in any group. Seventy-two percent of patients reached protein targets $\geq 1.3 \mathrm{~g} / \mathrm{kgBW} / \mathrm{d}$ within 4 days after initiation of enteral feeding, which was superior to the CTG (33\%). Post-hoc testing showed group differences of protein intake between HPG and CTG were significant at $t=72 \mathrm{~h}$ and $t=96 \mathrm{~h}$. Energy targets were met in both groups.

CONCLUSION: The HP:E formula containing 33\% whey protein hydrolysate is well tolerated in this tolerability study. Due to the HP: E ratio protein targets can be reached faster. Larger randomized trials are needed to confirm preliminary results.

TRIAL REGISTRATION: ClinicalTrials.gov Identifier: NCT02678325. Registered 2 May 2016.
\end{abstract}

European Journal of Clinical Nutrition (2022) 76:419-427; https://doi.org/10.1038/s41430-021-00956-9

\section{BACKGROUND}

Besides treatment for the underlying disease or insult, providing adequate nutritional support, according to current guidelines, is vital to counteract muscle wasting and loss of functional capacity associated with a critical illness. Due to its reduction of infectious complications, shorter ICU, and hospital stay [1], the enteral route is prioritized over parenteral nutrition (PN) [1-4]. Appropriate timing of nutritional support containing the required amounts of energy and protein in intensive care unit (ICU) patients has received considerable attention, in particular during the acute phase of critical illness [1,5-12]. Based on the available evidence mainly from large observational studies, current guidelines and expert recommendations support a protein intake in the range of $1.2-2.0 \mathrm{~g} / \mathrm{kg}$ body weight (BW) per day for critically ill patients $[1,2,13,14]$. While recommended protein targets for ICU patients have increased over time, energy targets were concurrently reduced, in particular for the acute phase of critical illness, which has been divided into "early period" for day 1 and 2, and "late period", for days 3-7 [1]. It is now generally accepted that energy targets in critical illness should be defined by indirect calorimetry (IC) whenever possible [1, 2]. If this tool is not available, oxygen consumption $\left(\mathrm{VO}_{2}\right)$ from pulmonary arterial catheter or carbon dioxide production derived from the ventilator $\left(\mathrm{VCO}_{2}\right)$ has been suggested as an alternative by Staples et al. [15]. In absence of the above mentioned $\mathrm{IC}, \mathrm{VO}_{2}$, and $\mathrm{VCO}_{2}$, a maximum of $20-25 \mathrm{kcal} / \mathrm{kg}$ $\mathrm{BW} /$ day should be provided during the acute phase with a possible increase to $25-30 \mathrm{kcal} / \mathrm{kg} /$ day in stable patients during the later phase of their ICU stay $[1,2,16]$.

Providing adequate amounts of protein and energy is of utmost importance for critically ill patients who are at high risk of malnutrition. In particular, during the acute phase of critical illness, the breakdown of muscle protein is enhanced to provide amino acids to foster the synthesis of acute-phase proteins, immune function, gluconeogenesis, and wound healing $[17,18]$.

\footnotetext{
${ }^{1}$ Intensive Care Unit, University Hospital Basel, Basel, Switzerland. ${ }^{2}$ Department of Clinical Nutrition, University Department of Geriatric Medicine Felix Platter, Basel, Switzerland. email: alexa.hollinger@usb.ch
} 
Inadequate nutrition support and immobility further aggravate muscle wasting and depletion of energy stores, resulting in prolonged morbidity and persistent physical weakness [11, 19]. However, the optimal amount of protein intake in critically ill patients is still a matter of debate [20].

Observational studies point at the possibility that a higher protein intake, especially during the early phase of critical illness, improves outcome and might reduce mortality [21-23]. However, the only study up to date, which examines the correlation between protein intake and reduced mortality using randomized controlled trials (RCT), is a meta-analysis that looks at RCTs between 1966 and 2015 and does not support the latter findings [24]. Yet, the doses of protein delivered in this review did not meet current guidelines, as they were only up to $1.02 \mathrm{~g} / \mathrm{kg} /$ day. Furthermore, only two out of 14 studies varied the allotment of protein whilst allocating the same amount of energy $[2,16]$.

The implementation of lower energy targets in line with guidelines to prevent overfeeding carries an associated risk of insufficient protein intake because nutritional prescriptions are usually based on energy targets rather than on protein targets. In fact, protein targets according to guidelines are rarely achieved with conventional enteral formulations providing only $40-60 \mathrm{~g}$ of protein per $1000 \mathrm{kcal}$. The possible resulting protein deficit can be critical in the acute phase of critical illness and has been shown to be associated with prolonged ventilation time and ICU stays in observational studies [6]. Another challenge in the provision of adequate amounts of protein is feeding intolerance, occurring with a prevalence of up to $75 \%$ in enterally fed critically ill patients [25]. Hence, ICU patients worldwide are commonly receiving considerably less than current protein recommendations, especially during early ICU stay $[4,14]$. Accordingly, experts conclude that enteral feeds with a higher protein-to-energy ratio should be chosen for critically ill patients $[4,6]$.

In the present prospective feasibility tolerability study, we investigated the use of a new enteral formula with a high proteinto-energy ratio (HP:E formula), providing $82 \mathrm{~g}$ protein per $1000 \mathrm{kcal}$ consisting of $100 \%$ whey protein hydrolysate, developed to meet the increased protein requirements of critically ill patients while avoiding energy overfeeding. The study was primarily aimed to assess the tolerability of the new formula in ICU patients and, secondly, to investigate whether patients receiving the HP:E enteral formula achieved their protein targets faster compared to a matched conventional therapy group (CTG) receiving an established standard enteral formula in our ICU with lower protein content. The aim was to achieve individualized protein targets of $\geq 1.3 \mathrm{~g} / \mathrm{kgBW} / \mathrm{d}$ with the HP:E formula within $96 \mathrm{~h}$ after the initiation of feeding.

\section{METHODS}

\section{Design, setting, and participants}

Critically ill patients admitted to the Surgical Intensive Care Unit of the University Hospital of Basel, Switzerland, between May 2016 and January 2017 were enrolled in this prospective, observational tolerability study. Patients aged 18 years and older were included if they were expected to stay at least $96 \mathrm{~h}$ in the ICU and were in need of EN during this period. Patients were excluded from the study for any of the following reasons: any oral intake, $B M I \leq 18 \mathrm{~kg} / \mathrm{m}^{2}$ or $\geq 35 \mathrm{~kg} / \mathrm{m}^{2}$, mechanical intestinal obstruction, intestinal perforation, severely impaired liver function, terminal state of cancer, $\geq 0.5 \mu \mathrm{g} / \mathrm{kg} / \mathrm{min}$ norepinephrine upon admission, pregnancy or contraindication for protein-rich nutrition (e.g., severe liver dysfunction). Although the study was carried out in a surgical ICU, medical patients fulfilling the inclusion criteria were eligible for enrollment too.

Informed consent was obtained from an independent physician and from the patient or his next of kin. This study has been approved by the Ethics Committee of Northwestern and Central Switzerland and was conducted in compliance with the protocol, the current version of the
Table 1. Nutritional composition of the HP:E formula (amounts given per $100 \mathrm{ml})$.

\begin{tabular}{|ll|}
\hline Energy & $122 \mathrm{kcal}$ \\
\hline Carbohydrates & $42 \%$ \\
\hline Protein & $33 \%$ \\
\hline Fat & $24 \%$ \\
\hline Fibers & $1 \%$ \\
\hline Carbohydrates & $12.9 \mathrm{~g}$ \\
\hline of which sugars & $8.0 \mathrm{~g}$ \\
\hline of which lactose & $\leq 0.5 \mathrm{~g}$ \\
\hline Protein & $10.0 \mathrm{~g}$ \\
\hline of which whey protein hydrolysate & $10.0 \mathrm{~g}$ \\
\hline Nitrogen & $1.57 \mathrm{~g}$ \\
\hline Fat & $3.2 \mathrm{~g}$ \\
\hline MCT & $1.28 \mathrm{~g}$ \\
\hline LCT & $1.92 \mathrm{~g}$ \\
\hline Saturated & $0.38 \mathrm{~g}$ \\
\hline Monounsaturated & $0.82 \mathrm{~g}$ \\
\hline Polyunsaturated & $0.72 \mathrm{~g}$ \\
\hline Fibers & $0.64 \mathrm{~g}$ \\
\hline Water & $80.5 \mathrm{ml}$ \\
\hline Osmolarity & $600 \mathrm{mosmol} / \mathrm{I}$ \\
\hline Osmolality & $740 \mathrm{mosmol} / \mathrm{kg} \mathrm{H} \mathrm{O}$ \\
\hline Minerals & \\
\hline Sodium & $175 \mathrm{mg} / 7.6 \mathrm{mmol}$ \\
\hline Potassium & $295 \mathrm{mg} / 7.5 \mathrm{mmol}$ \\
\hline Chloride & $160 \mathrm{mg} / 4.5 \mathrm{mmol}$ \\
\hline Calcium & $105 \mathrm{mg} / 2.6 \mathrm{mmol}$ \\
\hline Magnesium & $30 \mathrm{mg} / 1.2 \mathrm{mmol}$ \\
\hline Phosphorus & $70 \mathrm{mg} / 2.3 \mathrm{mmol}$ \\
\hline & \\
\hline
\end{tabular}

Declaration of Helsinki, the ICH-GCP, or ISO EN 14155 (as far as applicable) as well as all national legal and regulatory requirements.

\section{Interventions}

Patients prospectively enrolled in the high protein group received EN with the HP:E formula (Fresubin ${ }^{\circledast}$ Intensive, Fresenius Kabi, Bad Homburg, Germany), providing $1220 \mathrm{kcal}$ and $100 \mathrm{~g}$ whey protein hydrolysate per $1000 \mathrm{ml}$, for the duration of four study days or less in case of adequate oral food intake, discharge or death. The HP:E formula contains 24 energypercent, fat, thereof $\sim 40 \%$ as medium-chain triglycerides (MCT) and 42 energy-percent slow-release carbohydrate blend (isomaltulose and maltodextrin). The nutritional composition of the HP:E formula is shown in Table 1 . The study group was matched retrospectively with an equal number of patients who were admitted to the ICU in the same period of time and receiving enteral nutrition for over four days with a formula containing the same amount of energy but only a standard amount of protein (Isosource Protein Fiber Neutral Smartflex ${ }^{\circledR}$, Nestlé, Vevey, Switzerland) providing $1200 \mathrm{kcal}$ and $67 \mathrm{~g}$ protein per $1000 \mathrm{ml}$. In order to ensure the CTG's comparability, we matched for APACHE (Acute Physiology And Chronic Health) II score and gender. None of the patients in either group received PN.

All patients included in the study received the EN via nasogastric tube by continuous infusion over $24 \mathrm{~h}$ with an hour interval every $4-6 \mathrm{~h}$ to check for gastric residual volume (GRV). According to the local ICU feeding protocol [26], EN was initiated in all patients within 24-48 h after admission. After hemodynamic stabilization and under the precondition of a functioning gut, EN was started at an initial feeding rate/volume of $20 \mathrm{ml} / \mathrm{h}$ gradually increased by $10 \mathrm{ml} / \mathrm{h}$ every $4-6 \mathrm{~h}$ until the calculated target volume was reached. Current ESPEN guidelines recommend that gastrointestinal feeding should be delayed when GRV $>500 \mathrm{ml} / 6 \mathrm{~h}$ [1]. In 
order to anticipate possible intolerance, upon definition of study design authors chose a more conservative approach and decided not to increase the feeding rate with $\mathrm{GRV} \geq 300 \mathrm{ml}$ and to prescribe $10 \mathrm{mg}$ of metoclopramide IV three times daily. In case this treatment failed to enhance gastric motility the patient additionally received erythromycin $100 \mathrm{mg}$ IV four times a day. Ventilated patients did not receive any neuromuscular blocking agents.

The nutritional target for the HPG was to achieve a protein intake of $\geq 1.3 \mathrm{~g} / \mathrm{kgBW} / \mathrm{d}$ within $96 \mathrm{~h}$ after the initiation of feeding and to compare achievements to the CTG.

For the calculation of target volumes, the patient's BW was adjusted according to the body mass index (BMI). For patients with BMI values between $18.1 \mathrm{~kg} / \mathrm{m}^{2}$ and $19.9 \mathrm{~kg} / \mathrm{m}^{2}$, a BW corresponding to a BMl of $22 \mathrm{~kg} /$ $\mathrm{m}^{2}$ was used for all calculations. For patients with a $\mathrm{BMI} \geq 30 \mathrm{~kg} / \mathrm{m}^{2}$ to $34.9 \mathrm{~kg} / \mathrm{m}^{2}$, the calculations were made with a BW corresponding to a BMI of $25 \mathrm{~kg} / \mathrm{m}^{2}$. For all other patients, we used the actual BW. Since IC was not available at our institution, an approximate energy target according to recommendations $[2,16]$ was used.

\section{Data collection}

Upon inclusion, the following characteristics were recorded: admission category (medical or surgical) and diagnosis, relevant co-existing diseases prior to admission (i.e., diabetes, kidney disease, bedsores), as well as GRV and duration of mechanical ventilation. Patients in the HPG were further monitored for diarrhea, emesis, and laxatives/stool softeners in order not to miss any kind of intolerance. Laboratory values were measured at least once per day for $96 \mathrm{~h}$ after the feed initiation.

Laboratory values to calculate the APACHE \| score, the SAPS II (Simplified Acute Physiology score) score, and the NUTRIC (nutrition risk in critically ill) score were recorded during the first $24 \mathrm{~h}$ of ICU stay. Laboratory values for calculation of the sequential organ failure assessment (SOFA) score were recorded on a daily basis. Vital signs were monitored and automatically transmitted to the patient data management system and surveyed by a study investigator. Weight prior to admission was either obtained from the patient, relatives, general practitioners, and height was measured. The patient's BMl was calculated in order to determine the individual nutritional targets. Study data were recorded until $96 \mathrm{~h}$ after the initiation of EN.

NUTRIC score was calculated with the omission of IL-6 levels as a validated tool for the identification of critically ill patients most likely benefiting from artificial nutrition [27].

The intensive care nursing staff recorded data on protein and energy intake from EN using an electronic patient data monitoring system (MetaVision ${ }^{\circledR}$, Version V, iMDsoft; Tel Aviv, Israel).

\section{Outcomes}

The primary outcome of our study was the GI tolerability of the HP:E enteral formula during the first 4 days of continuous enteral feeding. Intolerance was defined as $\geq 300 \mathrm{ml}$ GRV per day, vomiting or the occurrence of diarrhea, defined as $\geq 3$ loose or liquid stools per day during the first 2 days. Diarrhea was only considered as a sign of GI intolerance during the first $48 \mathrm{~h}$ after initiation of EN. Patients without any bowel movements were prescribed laxatives by the third day according to local practice and therefore were prone to develop loose stools, which could not be distinguished from diarrhea related to the intake of the study formula.

Secondary outcomes were the total amount of protein and energy delivered over the first $96 \mathrm{~h}$ of feeding as well as the percentage of patients reaching their protein target in the HPG compared to the CTG.

According to the treatment protocol of the surgical ICU, physiotherapists started moving patients' limbs passively for $30 \mathrm{~min}$ from day two after admission in case their condition allowed it.

\section{Data analysis and statistics}

Descriptive data are reported as absolute values, mean \pm standard deviation (SD) if appropriate, or median and interquartile range (IQR) or percentage.

We estimated a sample size including $10 \%$ loss to follow-up of 25 patients in total for a power of 0.8 to see a modest difference in protein or energy uptake in groups with a significance level of alpha of 0.05 .

Data analysis on differences in protein and energy intake was performed with two-way mixed ANOVA for time, group and interaction. Data met the conditions of normality and homoscedasticity as assured by visual inspection using QQ-plots and Levene's test. Upon significant ANOVA findings, post-hoc $t$-tests for differences of group means were performed with a Bonferroni correction.

Treating doctors and nursing staff were not part of the study team and therefore independent in their medical decisions.

\section{RESULTS}

\section{Enrollment and baseline characteristics}

Twenty-five patients were enrolled in the HPG to receive the HP:E enteral formula. Two patients had to be excluded on the first study day: one patient died and one patient achieved adequate oral food intake and was transferred to a regular ward. Over the intervention period, two more patients dropped out by day 3 and three more patients by day 4 , due to death $(n=1)$ or transfer to a regular ward with adequate oral intake $(n=4)$. Hence, the final intervention group consisted of 18 patients eventually who completed 4 days of feeding with the high protein enteral formula. Participant flow through the HPG is shown in Fig. 1. The HPG was matched with 18 patients during the same period of time who received EN with the conventional formula for at least 4 days. We matched the group for APACHE II score and gender on the basis of our eligibility criteria: at baseline, the median APACHE II score of both groups was 21.0 (IQR) for HPG 19.0-24.8, for CTG $19.3-25.0$ equal to a mortality risk of $40 \%$. In both groups, there were 4 female and 14 male patients.

Patients in the HPG and CTG (Table 2) were also comparable with regard to baseline demographic characteristics like age, weight and BMI, enteral nutrition risk (NUTRIC score), and organ

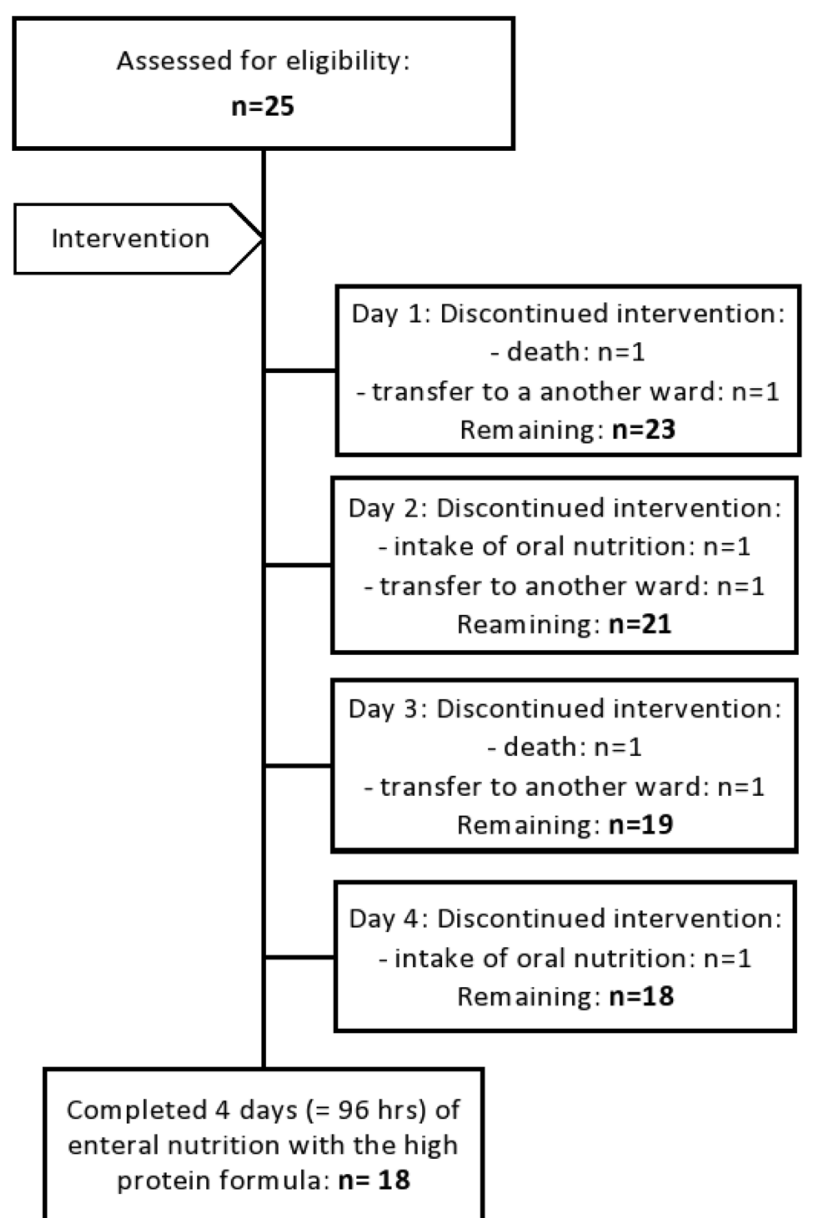

Fig. 1 Consort diagram of included study patients showing the patient flow through the HPG. HPG, high protein group; hrs, hours. 
Table 2. Baseline characteristics and admission diagnoses reported as median (IQR) or mean \pm SD as $N(\%)$.

\begin{tabular}{|lll}
\hline $\begin{array}{l}\text { Baseline characteristics } \\
\boldsymbol{N}\end{array}$ & $\begin{array}{l}\text { High protein } \\
\text { formula group } \\
\text { (HPG) 18 }\end{array}$ & $\begin{array}{l}\text { Conventional } \\
\text { formula group } \\
\text { (CFG) 18 }\end{array}$ \\
\hline Elective/emergency & $1 / 17$ & $5 / 13$ \\
\hline Age, years & $73.0(56.3-76.0)$ & $70.0(67.0-75.8)$ \\
\hline Gender, f/m & $4 / 14$ & $4 / 14$ \\
\hline Weight, kg & $78.5(72.8-93.8)$ & $80.0(71.3-96.0)$ \\
\hline BMl, kg/m ${ }^{2}$ & $27.8(23.1-31.8)$ & $26.9(23.4-31.3)$ \\
\hline NUTRIC score & $6.0(4.3-6.0)$ & $5.5(4.0-6.0)$ \\
\hline Low (0-5) & 8 & 9 \\
\hline High (6-10) & 10 & 9 \\
\hline APACHE II & $21.0(19.0-24.8)$ & $21.0(19.3-25.0)$ \\
\hline SOFA score & $8.9 \pm 2.6$ & $9.1 \pm 3.4$ \\
\hline Requirement for MV & D1: 16/18 (89\%) & D1: 18/18 (100\%) \\
\hline Admission diagnosis & D4: $15 / 18(83 \%)$ & D4: 9/18 $(50 \%)$ \\
\hline Post cardiac surgery & $7(39 \%)$ & $8(44 \%)$ \\
\hline Trauma & $4(22 \%)$ & $1(6 \%)$ \\
\hline Sepsis & $2(11 \%)$ & $0(0 \%)$ \\
\hline Respiratory failure & $2(11 \%)$ & $2(11 \%)$ \\
\hline Other & $3(17 \%)$ & $7(39 \%)$ \\
\hline MV & & \\
\hline
\end{tabular}

MV mechanical ventilation.

Table 3. Incidence of feeding intolerance reported as $N(\%)$ with the HP:E formula vs. controls receiving a standard enteral formula. Diarrhea defined as $\geq 3$ loose or liquid stools per day.

\begin{tabular}{|c|c|c|}
\hline & $\begin{array}{l}\text { HP:E } \\
\text { formula (HPG) }\end{array}$ & $\begin{array}{l}\text { Standard } \\
\text { formula (CTG) }\end{array}$ \\
\hline GRV $\geq 300 \mathrm{ml}$ (any day) & $6(33.3 \%)^{a}$ & $6(33.3 \%)^{\mathrm{a}}$ \\
\hline GRV $\geq 300 \mathrm{ml}$ (day 1) & $3(16.7 \%)$ & - \\
\hline GRV $\geq 300 \mathrm{ml}$ (day 2) & $2(11.1 \%)$ & - \\
\hline GRV $\geq 300 \mathrm{ml}$ (day 3) & $1(5.6 \%)$ & - \\
\hline GRV $\geq 300 \mathrm{ml}$ (day 4) & $2(11.1 \%)$ & - \\
\hline GRV $\geq 500 \mathrm{ml}$ (any day) & $3(16.7 \%)$ & $1(5.6 \%)$ \\
\hline $\begin{array}{l}\text { Diarrhea ( } \geq 1000 \mathrm{ml} \text {, } \\
\text { any day) }\end{array}$ & $2(11.1 \%)$ & NA \\
\hline $\begin{array}{l}\text { Emesis (number of } \\
\text { patients) }\end{array}$ & $2(8.7 \%)$ & NA \\
\hline EN discontinuation & 0 & 0 \\
\hline
\end{tabular}

failure (SOFA score). The most frequent admission category in both groups was post-cardiac surgery.

\section{Tolerance of enteral feeding (primary outcome)}

Overall six patients in each group experienced a GRV of $\geq 300 \mathrm{ml}$, which corresponds to $33.3 \%$ (Table 3 ). In the HPG, three patients (16.7\%) experienced a GRV of $\geq 500 \mathrm{ml}$ on one of four study days, in the CTG there was one patient (5.6\%) affected by a GRV of $\geq 500 \mathrm{ml}$. On days 1 and $2,61.1 \%$ and $83.3 \%$ of patients respectively, received propulsive medication (metoclopramide, erythromycin) and/or stool softeners (lactulose) in the HPG according to the routine protocol of the surgical ICU and $27.3 \%$ were given laxatives on the first two days. Two more patients were suffering from emesis and vomiting lasting for 1-2 days (Table 3 ). Medication, diarrhea, and vomiting were not recorded in the CTG. There was no need for discontinuation of EN in any patient in either group.

\section{Protein and energy intakes}

The average time from admission to initiation of enteral feeding after hemodynamic stabilization was $37 \pm 23 \mathrm{~h}$ in the HPG and $40 \pm 28 \mathrm{~h}$ in the control group. In both groups, 14 patients $(78 \%)$ received EN within $48 \mathrm{~h}$ following admission. On average, patients in the HPG received $0.4 \mathrm{~g} / \mathrm{kgBW} / \mathrm{d}$ of protein with the HP:E formula during the first $24 \mathrm{~h}$ after admission (Table 4). On the second day, the average protein intake in the HPG increased to $1.1 \mathrm{~g} / \mathrm{kgBW} / \mathrm{d}$. Within $72 \mathrm{~h}$ after initiation of feeding, patients in the HPG achieved their protein target of $\geq 1.3 \mathrm{~g} / \mathrm{kgBW} / \mathrm{d}$ with an average of $1.5 \mathrm{~g} / \mathrm{kgBW} / \mathrm{d}$. On days 3 and $4,72 \%$ of patients in the HPG met their individual daily protein target. In contrast, patients in the CTG received an average of $0.9 \mathrm{~g}$ of protein $/ \mathrm{kgBW} / \mathrm{d}$ by day 3 and 4 and only $22 \%$ and $33 \%$, respectively, reached their individual protein intake target of $\geq 1.3 \mathrm{~g} / \mathrm{kgBW} / \mathrm{d}$ (Table 5). The HPG met the average caloric target of $20 \mathrm{kcal} / \mathrm{kgBW} / \mathrm{d}$ on day 3 with $101 \%$ and on day 4 with $97 \%$. A total of $61 \%$ of patients reached their individual target on both days, whereas in the CTG, 108\% and $114 \%$ met the average target by day 3 and 4 , respectively, and $67 \%$ of patients reached their individual target of $20 \mathrm{kcal} / \mathrm{kgBW} / \mathrm{d}$ (Table 5). On each study day, the average feeding volume was lower in the HPG vs. the CTG (Table 4).

Analysis of variance respecting repeated measures at different time points within groups showed a significant main effect of time with an $\eta_{g}{ }^{2}>0.5$, i.e., explaining more than $50 \%$ of the variance, for all measurements. The main effect of the group was also significant for all measurements, explaining up to $17 \%$ of the variance (e.g., BW adjusted protein intake $F=27.77, p \leq 0.0001$, $\eta_{g}{ }^{2}=0.17$ ). HPG thus showed higher amounts of protein (mean = $4.5 \mathrm{~g}$ ) compared to the CTG (mean $=2.8 \mathrm{~g}$ ). The interaction term was not significant in any analysis. Considering the post-hoc testing, it can be seen that group differences in protein intake between HPG and CTG were significant at $t=72 \mathrm{~h}$ and $t=96 \mathrm{~h}$ (Fig. 2). As expected, there were not any group differences in energy intake (Fig. 3).

\section{Glycaemic control and laboratory values}

The median peak daily glucose level in the HPG was $8.9 \mathrm{mmol} / \mathrm{l}$ (8.6-11.1 $\mathrm{mmol} / \mathrm{l})$ with glucose being the highest on day 4 with $10.1 \mathrm{mmol} / \mathrm{l}$. In the CTG, the median peak daily glucose level was $10.3 \mathrm{mmol} / \mathrm{l}(9.2-11.2 \mathrm{mmol} / \mathrm{l})$, the highest value was scored on day 2 (Table 6). None of the patients needed more than 25 units of insulin per day, regardless of the presence of diabetes prior to admission. Table 6 shows the course of selected laboratory values over time in the HPG. Plasma ammonium was slightly elevated, yet remained within normal range, at 72 and $96 \mathrm{~h}$ after initiation of enteral feeding. Triglycerides remained stable and within normal range throughout the study period. The median plasma creatinine level was a little over the upper limit of the normal range $(42-80 \mu \mathrm{mol} / \mathrm{l})$ and ranged from 104 to $125 \mathrm{mcmol} / \mathrm{l}$ over the 4 days with a median of $116 \mathrm{mcmol} / \mathrm{l}$ on day 4 . In the CTG, creatinine remained in the normal range throughout the study. Urea increased in both groups over the study period and values were above the upper limit of a normal range $(3.0-7.8 \mathrm{mmol} / \mathrm{l})$ throughout the study in the HPG and from $72 \mathrm{~h}$ after initiation of enteral feeding until the end of the study period in the CTG.

\section{Nitrogen excretion}

Twenty-four-hour urinary urea nitrogen (UUN) excretion was assessed in the HPG after 24 and $48 \mathrm{~h}$ feeding time, respectively, and was well within the normal range (Table 6). Setting the UUN excretion rates at 24 and $48 \mathrm{~h}$ against the enteral protein intakes 
Table 4. Energy and protein intakes over the first $96 \mathrm{~h}$ of enteral feeding reported per study day, high protein group (HPG) vs. control group (CTG). Values are given as mean intakes over $24 \mathrm{~h}$ reported per $\mathrm{kgBW}$, as total daily intakes, and as a percentage of patients reaching their protein/energy targets on each study day.

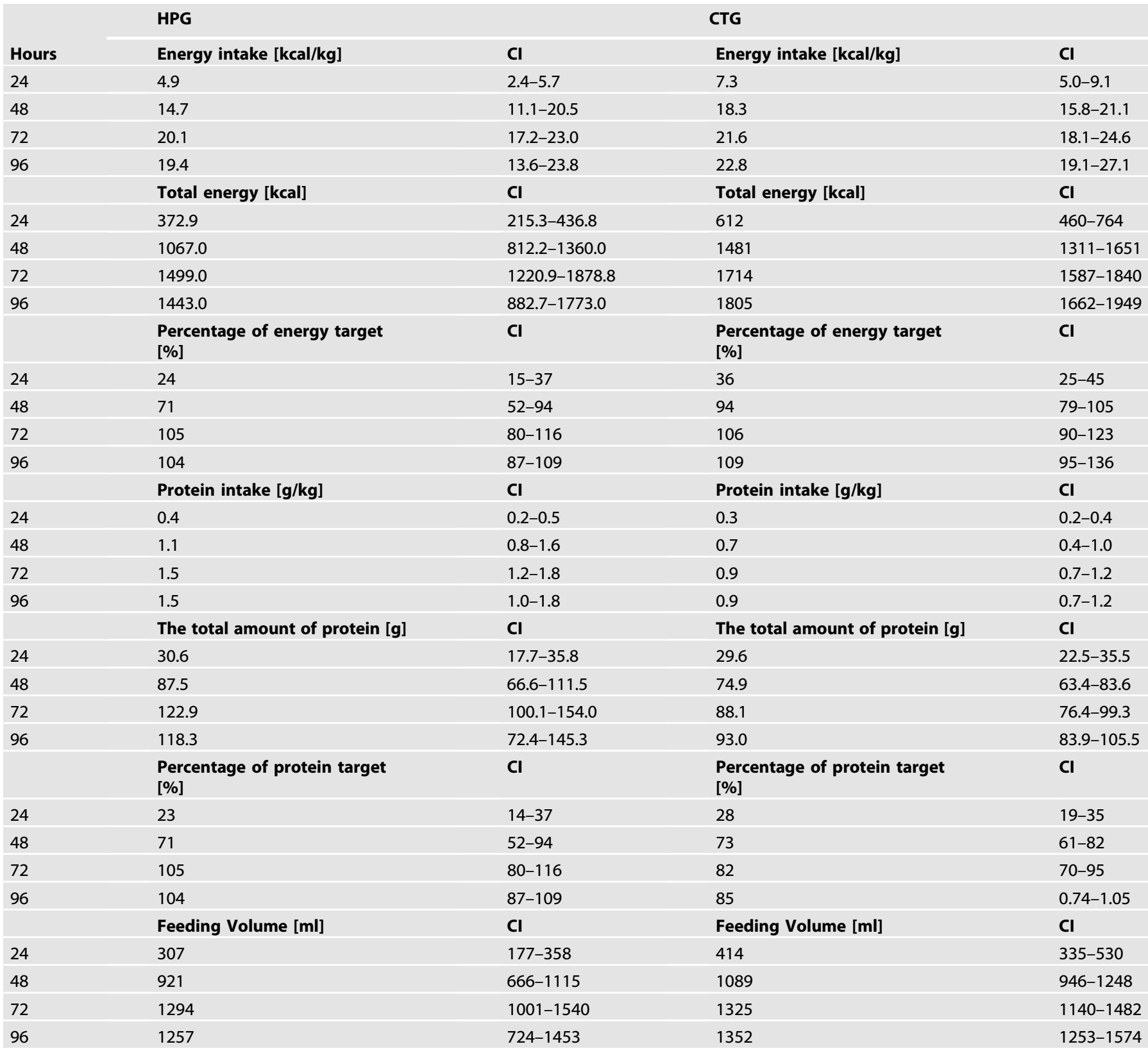

over the respective time intervals $(31$ and $88 \mathrm{~g}$, corresponding to 5.0 and $4.1 \mathrm{~g}$ nitrogen, respectively), the calculated nitrogen balance was $-1.3 \mathrm{~g} / \mathrm{d}$ after $24 \mathrm{~h}$ and $5.5 \mathrm{~g} / \mathrm{d}$ after $48 \mathrm{~h}$ according to the formula by Blackburn and Bistrian [28].

\section{DISCUSSION}

The findings of the BEntHiPro prospective tolerability study revealed that the new HP:E enteral formula with $100 \%$ whey protein hydrolysate appears to be equally well tolerated in terms of GRV in critically ill patients compared to an established enteral formula. In addition, a protein target of $\geq 1.3 \mathrm{~g} / \mathrm{kg}$ BW/ $\mathrm{d}$ could be reached within $72 \mathrm{~h}$ after initiation of enteral feeding in $72 \%$ of patients with the administration of this enteral formula, while targeted energy intake was reached in $61 \%$.
As would be expected, we found a significant effect of time for both energy and protein intake with repeated measures showing consistent time courses for each subject. The effect of the group was also found to be significant in protein intake corrected for BW. The interaction between time and group was not significant, which was to be expected for the total patient number and suspected modest effect. In addition, more subtle differences in protein intake at earlier time points may have been identified with more power, i.e., a higher total number of patients.

In terms of overall GI intolerance including emesis and diarrhea, patients did not experience gastrointestinal intolerance requiring interruption of enteral nutrition in any patient. However, as it turned out during our tolerability study, diarrhea did not qualify as the primary outcome for tolerability since $83 \%$ of all patients received several laxatives and/or stool softeners which 
Table 5. Percentage of patients reaching their energy and protein goals after $24,48,72$, and $95 \mathrm{~h}$ of enteral feeding, respectively (calculations are rounded to one digit after the decimal point for better readability).

\begin{tabular}{|c|c|c|c|c|}
\hline & \multicolumn{2}{|l|}{ HPG $(n=18)$} & \multicolumn{2}{|l|}{ CTG $(n=18)$} \\
\hline & $\begin{array}{l}\text { Patients reaching } \geq 20 \mathrm{kcal} / \mathrm{kg} / \\
\text { day energy }(\%)\end{array}$ & $\begin{array}{l}\text { Patients reaching } \geq 1.3 \mathrm{~g} / \mathrm{kg} / \\
\text { day protein }(\%)\end{array}$ & $\begin{array}{l}\text { Patients reaching } \geq 20 \mathrm{kcal} / \mathrm{kg} / \\
\text { day energy }(\%)\end{array}$ & $\begin{array}{l}\text { Patients reaching } \geq 1.3 \mathrm{~g} / \mathrm{kg} / \\
\text { day protein }(\%)\end{array}$ \\
\hline $48 \mathrm{~h}$ & 27.8 & 38.9 & 33.3 & 5.6 \\
\hline $72 \mathrm{~h}$ & 61.1 & 72.2 & 66.7 & 22.2 \\
\hline $96 \mathrm{~h}$ & 61.1 & 72.2 & 66.7 & 33.3 \\
\hline
\end{tabular}

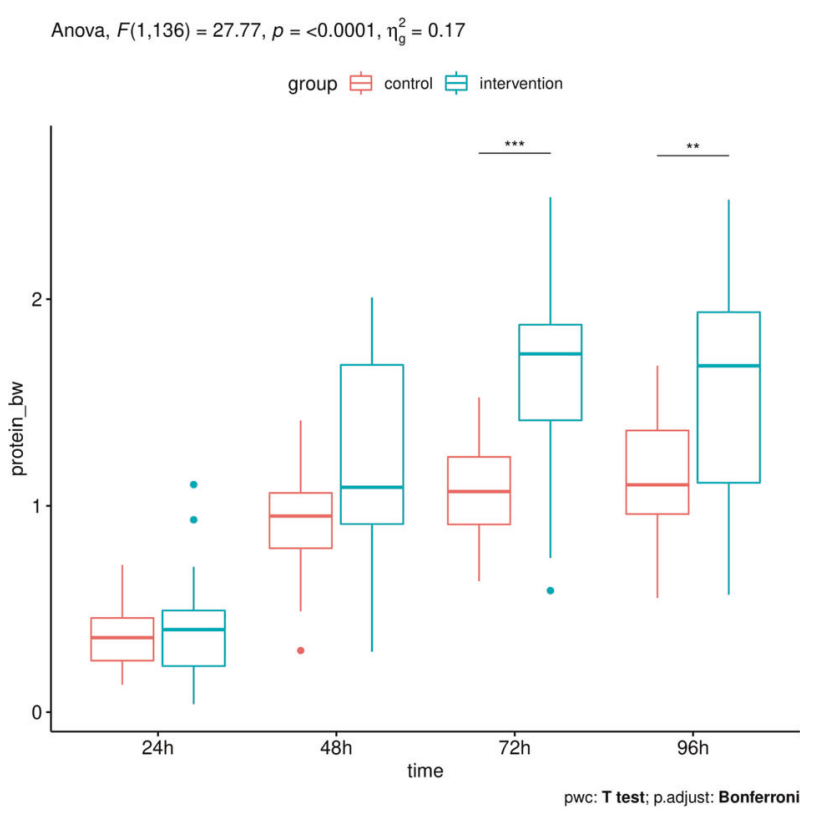

Fig. 2 Boxplots of for protein intake per kgBW over 24, 48, 72, and $96 \mathrm{~h}$ using two-way ANOVA with Bonferroni correction. ANOVA, analysis of variance; BW, body weight.

Anova, $F(1,136)=9.02, p=0.003, \eta_{g}^{2}=0.06$

$$
\text { group } \risingdotseq \text { control } \dot{\varphi} \text { intervention }
$$

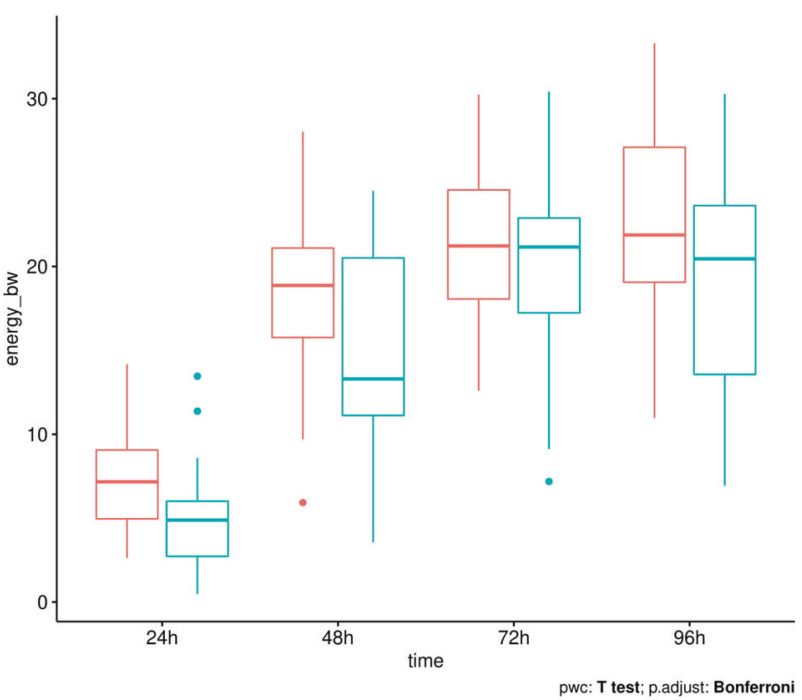

Fig. 3 Boxplots for energy intake per $\mathbf{k g B W}$ over $24,48,72$, and $96 \mathrm{~h}$ using two-way ANOVA with Bonferroni correction. ANOVA, analysis of variance, BW, body weight. considerably biased the interpretation of diarrhea as an "adverse event". The incidence of GI intolerance in terms of high GRV with the HP:E formula was slightly lower compared to a previous study with the same product, reporting high GRVs $(>250 \mathrm{ml})$ in $15 \%$ of ventilated ICU patients over the first 4 days [29]. In contrast, a recent $\mathrm{RCT}$ investigating an intact protein enteral formula providing $63 \mathrm{~g}$ of mixed intact protein from whey, casein, pea, and soy per $1000 \mathrm{ml}$ over 10 days in a comparable patient setting reported a considerable greater incidence of $\mathrm{Gl}$ intolerance with high GRVs (>500 ml) in $18.2 \%$ of patients [30].

Rice et al. [31] also conducted a study with an increased amount of protein in their randomized open-label trial using an experimental formula with high-whey peptides (37\%) and low carbohydrates (29\%) compared to a standard formula with $25 \%$ of protein and $45 \%$ of carbohydrates. On days $1-5$, they provided $1.1 \pm 0.3 \mathrm{~g} / \mathrm{kg} / \mathrm{IBW} / \mathrm{d}$ and $1.2 \pm 0.4 \mathrm{~g} / \mathrm{kg} \mathrm{IBW} / \mathrm{d}$ protein, respectively. Although they reported an increase in the number of patients showing abdominal distension in the high-protein group, they did not record a difference in the number of patients requiring $\mathrm{EN}$ discontinuation.

With regard to the secondary study outcomes (i.e., total amounts of protein and energy delivered over the first $96 \mathrm{~h}$ after initiation of enteral feeding), the HP:E formula proved to be clearly superior to an established enteral formula in terms of providing adequate amounts of protein according to individual targets in line with current guidelines and expert recommendations for critically ill patients $[1,2,13,14]$ : $67 \%$ of patients reached protein targets $\geq 1.3 \mathrm{~g} / \mathrm{kgBW} / \mathrm{d}$ within 4 days after initiation of enteral feeding. Importantly, protein targets were achieved in the HPG while the provision of energy did not overly exceed requirements (not more than $101 \%$ of the goal amount).

In the present investigation, more than half of all patients (56\%) in the HPG should be expected to benefit particularly from early high protein nutrition since their NUTRIC score indicated a high nutrition risk.

Whey protein is rated as a "fast protein" producing a rapid and pronounced postprandial rise in blood amino acids, in particular of leucine [32-34]. In the study by Looijaard et al. [29], significant increases in plasma levels of essential amino acids, including branched-chain amino acids and leucine, were seen on study days 2 and 4 vs. baseline. Thus, the $100 \%$ whey protein hydrolysatebased enteral formula effectively increased the availability of essential amino acids for protein synthesis during the early phase of critical illness. Tracer studies have previously confirmed that protein derived from early enteral nutrition is effectively used in critically ill patients for body protein accretion during the first week of ICU treatment [35]. Nitrogen balances calculated from UUN excretion rates in the present study suggest that a state of nitrogen anabolism was reached with the HP:E formula already within the first $48 \mathrm{~h}$. This finding indicates that the amino acids derived from the whey protein hydrolysate administered were largely retained in the body to counteract protein catabolism.

In contrast, other protein sources are less suitable to meet the specific needs of critically ill patients. Casein is prone to coagulation, delaying gastric emptying and absorption [36]. Pea 
Table 6. The course of specific laboratory values over time in the HP:E formula (HPG) and control formula (CTG) groups reported as median (IQR). Values in brackets indicate the normal range.

\begin{tabular}{|c|c|c|c|c|c|}
\hline & Admission & $24 \mathrm{~h}$ & $48 h$ & $72 \mathrm{~h}$ & $96 \mathrm{~h}$ \\
\hline \multicolumn{6}{|c|}{ Peak daily blood glucose $(6-10 \mathrm{mmol} / \mathrm{l})$} \\
\hline HPG & $9.1(7.2-11.4)$ & $9.1(7.7-10.3)$ & $9.1(7.7-9.6)$ & $9.2(7.9-10.5)$ & $10.1(9.0-10.6)$ \\
\hline CTG & NA & $8.8(7.4-10.3)$ & $11.2(9.1-12.4)$ & $9.9(9.0-12.5)$ & $9.7(8.9-10.8)$ \\
\hline \multicolumn{6}{|c|}{ Ammonium $(15-55 \mu \mathrm{mol} / \mathrm{l})$} \\
\hline HPG & $33(27-39)$ & $34(29-39)$ & $32(25-49)$ & $43(25-49)$ & $39(34-48)$ \\
\hline CTG & NA & NA & NA & NA & NA \\
\hline HPG & $111(90-152)$ & $104(89-154)$ & $119(95-152)$ & $125(96-166)$ & $116(82-160)$ \\
\hline CTG & $75(55-88)$ & $77(62-88)$ & $69(53-86)$ & $64(47-91)$ & $65(47-89)$ \\
\hline \multicolumn{6}{|c|}{ Triglycerides (<1.8 mmol/l) } \\
\hline HPG & $1.3(1.02-1.53)$ & $1.3(1.03-1)$ & $1.2(1.25-2.16)$ & $1.4(1.03-2.28)$ & $1.4(0.88-1.6)$ \\
\hline $\mathrm{CtG}$ & NA & NA & NA & NA & NA \\
\hline \multicolumn{6}{|c|}{$24 \mathrm{~h}$ UUN $(83-532 \mathrm{mmol} / 24 \mathrm{~h})$} \\
\hline HPG & NA & $107(53-163)$ & $174(148-270)$ & NA & NA \\
\hline CTG & NA & NA & NA & NA & NA \\
\hline
\end{tabular}

UUN urinary urea nitrogen, NA not available.

protein is considerably lower than whey protein in branched-chain amino acids and in leucine while being deficient in sulfurcontaining amino acids [37]. In the study by van Zanten et al. [30], investigating an enteral formula containing a mixture of intact proteins derived from whey, casein, pea, and soy, a higher increase in total serum amino acids was reported on day 5 with the test product compared to a standard high protein formula. Yet, this study did not report any data on specific amino acids, in particular on essential amino acids and leucine.

Ammonium and triglyceride parameters did not show any clinically relevant changes or abnormalities in response to four days of feeding with the HP:E enteral formula. There was no hyperammonaemia throughout the study, indicating that, in this group of critically ill patients, the amounts of nitrogen administered over the first $96 \mathrm{~h}$ of feeding did not exceed the functional capacities of the liver and kidneys. BUN increased over the study period in both groups and, in the HPG, values were above the normal range already at baseline, as it is frequent in critical illness $[38,39]$. In the present study, there were five patients with AKI grade $\mathrm{l}$, defined as creatinine $\geq 1.5$ times of normal, at $96 \mathrm{~h}$ in the HPG. No patient developed AKI in the CTG. This finding needs careful monitoring in a subsequent larger trial in order to find out whether this difference in acute kidney injury is due to the small size of this pre-trial, due to a selection bias, or due to the higher amount of protein administered. In relation to this, it should also be examined whether the increased urea synthesis in the HPG is due to the enhanced amino acid oxidation, which has been observed in critical illness [40]. However, in a recently published study comparing high-protein and non-high-protein nutrition in critically ill patients, Suzuki and colleagues concluded that the high-protein group had significantly lower 28- and 90-day mortality and significantly greater delta-BUN, also after propensity score matching, but that delta-BUN might not be associated with outcomes [41].

We acknowledge that the study has several limitations. First, because the study was conceived as a tolerability study, only a small number of patients were included and as more patients dropped out during the intervention than expected, the study was not powered to assess any effects of the study nutrition on major clinical outcomes. Larger randomized trials are needed to confirm its tolerance and effect on patient outcomes. Second, this was not an RCT, but findings with HP:E formula were compared to a matched CTG with similar disease characteristics and feeding targets receiving an established enteral formula. Third, the meaningfulness of the findings is also limited by the fact that information on patients' BW, required for all calculations of energy and protein targets, was obtained from questioning the patient, relatives, or general practitioners for reasons of practicability in an ICU setting. Also, patients at the obese end of the BMI spectrum were excluded. According to the guidelines, patients with BMI > $40 \mathrm{~kg} / \mathrm{m}^{2}$ require $11-14 \mathrm{kcal}$ and up to $2.5 \mathrm{~g}$ protein $/ \mathrm{kg} \mathrm{IBW} \mathrm{[2].} \mathrm{For}$ a patient with a BMI of $40 \mathrm{~kg} / \mathrm{m}^{2}(170 \mathrm{~cm}, 120 \mathrm{~kg})$ this would translate to $1320-1680 \mathrm{kcal}$ and $180 \mathrm{~g}$ protein. The high-protein product provides $100 \mathrm{~g}$ of protein in $1220 \mathrm{kcal}$. Therefore, we would not reach the protein target with this product.

As a matter of fact, the amount of protein allocated should be derived by the lean body mass rather than the actual BW as it is still customary for most studies including this observational tolerability study and the studies mentioned [42]. It is about the protein pool of the body that we want to stop from draining which differs substantially from the whole body mass. It has been known for some decades now that total body skeletal muscle mass can be accurately measured by the third lumbar vertebra (L3) on abdominal computed tomography (CT) [43, 44]. Virtually any patient hospitalized in the ICU has a CT of the abdomen and it is unclear why this measurement has not been used more widely. Finally, findings with regard to nitrogen balance must be interpreted with caution since the classic nitrogen balance estimation [28] underestimates non-urea urinary nitrogen losses in many critically ill patients [45]. Moreover, the suitability of nitrogen balances as a measure of protein adequacy in critically ill patients has been questioned due to the associated risk of nitrogen intake over- and nitrogen excretion underestimation and the difficulty in obtaining a steady state over short periods of time (48 h) $[14,46-48]$. Nevertheless, as several authors have pointed out correctly $[22,49,50]$ : not every protein-ratio fits every critically 
ill patient. The loss of protein depends on the disease itself, age, and weight, to name but a few.

With the above-demonstrated insights made with this prospective observational study, consent has already been obtained from the responsible Ethics Committee to perform the doubleblind, randomized controlled clinical trial to compare an HP enteral formula with a standardized high carbohydrate product on total calorie and protein intake which will include the patients recruited for this trial.

\section{CONCLUSION}

An enteral formula with an HP:E ratio containing 33\% whey protein hydrolysate as a protein source appears to be suitable for early enteral feeding of critically ill patients requiring mechanical ventilation. However, larger and randomized trials are needed in order to recommend its use as a standard of care in the ICU. Due to the good $\mathrm{Gl}$ tolerance, individual protein targets in line with current recommendations ( $\geq 1.3 \mathrm{~g} / \mathrm{kgBW} / \mathrm{d}$ ) could be met within $72 \mathrm{~h}$ after initiation of enteral feeding with the HP:E formula, while, over the same period of time, energy provision was virtually met, but did not exceed a moderate caloric target of $20 \mathrm{kcal} / \mathrm{kgBW} / \mathrm{d}$. The new HP:E formula is thus in line with recent expert statements calling for enteral feeds with a higher protein-to-energy ratio to meet current guidelines for critical illness while the risk of energy overfeeding and hyperglycemia is minimized.

\section{DATA AVAILABILITY}

Prof Martin Siegemund had full access to all data in the study and takes responsibility for the integrity of the data and the accuracy of the data analysis.

\section{REFERENCES}

1. Singer $P$, Blaser AR, Berger MM, Alhazzani W, Calder PC, Casaer MP, et al. ESPEN guideline on clinical nutrition in the intensive care unit. Clin Nutr. 2019;38:48-79.

2. McClave SA, Taylor BE, Martindale RG, Warren MM, Johnson DR, Braunschweig C, et al. Guidelines for the provision and assessment of nutrition support therapy in the adult critically ill patient: society of critical care medicine (SCCM) and American society for parenteral and enteral nutrition (A.S.P.E.N.). JPEN J Parenter Enter Nutr. 2016;40:159-211.

3. Dhaliwal R, Cahill N, Lemieux M, Heyland DK. The Canadian critical care nutrition guidelines in 2013: an update on current recommendations and implementation strategies. Nutr Clin Pract. 2014;29:29-43.

4. Taylor S, Dumont N, Clemente R, Allan K, Downer C, Mitchell A. Critical care: meeting protein requirements without overfeeding energy. Clin Nutr ESPEN. 2016;11:e55-62.

5. Koekkoek K, van Zanten ARH. Nutrition in the ICU: new trends versus oldfashioned standard enteral feeding?. Curr Opin Anaesthesiol. 2018;31:136-43.

6. Berger MM, Soguel L, Charriere M, Theriault B, Pralong F, Schaller MD. Impact of the reduction of the recommended energy target in the ICU on protein delivery and clinical outcomes. Clin Nutr. 2017;36:281-7.

7. Weijs PJ, Stapel SN, de Groot SD, Driessen RH, de Jong E, Girbes AR, et al. Optimal protein and energy nutrition decreases mortality in mechanically ventilated, critically ill patients: a prospective observational cohort study. JPEN. 2012;36:60-68.

8. Compher C, Chittams J, Sammarco T, Nicolo M, Heyland DK. Greater protein and energy intake may be associated with improved mortality in higher risk critically ill patients: a multicenter, multinational observational study. Crit Care Med. 2017;45:156-63.

9. Song JH, Lee HS, Kim SY, Kim EY, Jung JY, Kang YA, et al. The influence of protein provision in the early phase of intensive care on clinical outcomes for critically ill patients on mechanical ventilation. Asia Pac J Clin Nutr. 2017;26:234-40.

10. Nicolo M, Heyland DK, Chittams J, Sammarco T, Compher C. Clinical outcomes related to protein delivery in a critically ill population: a multicenter, multinational observation study. JPEN J Parenter Enter Nutr. 2016;40:45-51.

11. Yeh DD, Fuentes E, Quraishi SA, Cropano C, Kaafarani H, Lee J, et al. Adequate nutrition may get you home. J Parenter Enter Nutr. 2016;40:37-44.

12. Arabi YM, Casaer MP, Chapman M, Heyland DK, Ichai C, Marik PE, et al. The intensive care medicine research agenda in nutrition and metabolism. Intensive Care Med. 2017;43:1239-56.
13. Weijs PJ, Dickerson RN, Heyland DK, Moore FA, Rugeles SJ, McClave SA. Experimental and outcome-based approaches to protein requirements in the intensive care unit. Nutr Clin Pract. 2017;32:77s-85s.

14. Heyland DK, Weijs PJ, Coss-Bu JA, Taylor B, Kristof AS, O'Keefe GE, et al. Protein delivery in the intensive care unit: optimal or suboptimal?. Nutr Clin Pract. 2017;32(1_suppl):58s-71s.

15. Stapel SN, de Grooth HJ, Alimohamad H, Elbers PW, Girbes AR, Weijs PJ, et al. Ventilator-derived carbon dioxide production to assess energy expenditure in critically ill patients: proof of concept. Crit Care. 2015;19:370.

16. Singer $P$, Hiesmayr M, Biolo G, Felbinger TW, Berger MM, Goeters $C$, et al. Pragmatic approach to nutrition in the ICU: expert opinion regarding which calorie protein target. Clin Nutr. 2014;33:246-51.

17. Preiser JC, Ichai C, Orban JC, Groeneveld AB. Metabolic response to the stress of critical illness. Br J Anaesth. 2014;113:945-54.

18. Puthucheary ZA, Rawal J, McPhail M, Connolly B, Ratnayake G, Chan P, et al. Acute skeletal muscle wasting in critical illness. JAMA. 2013;310:1591-600.

19. Martindale RG, Heyland DK, Rugeles SJ, Wernerman J, Weijs PJ, Patel J, et al. Protein kinetics and metabolic effects related to disease states in the intensive care unit. Nutr Clin Pract. 2017;32:21s-29s.

20. Arabi YM, Al-Dorzi HM, Sadat M. Protein intake and outcome in critically ill patients. Curr Opin Clin Nutr Metab Care. 2020;23:51-58.

21. Allingstrup MJ, Esmailzadeh N, Wilkens Knudsen A, Espersen $\mathrm{K}$, Hartvig Jensen $T$, Wiis J, et al. Provision of protein and energy in relation to measured requirements in intensive care patients. Clin Nutr. 2012;31:462-8.

22. Weijs PJ, Looijaard WG, Beishuizen A, Girbes AR, Oudemans-van Straaten HM. Early high protein intake is associated with low mortality and energy overfeeding with high mortality in non-septic mechanically ventilated critically ill patients. Crit Care. 2014;18:701.

23. Leyderman I, Yaroshetskiy A, Klek S. Protein requirements in critical illness: do we really know why to give so much?. JPEN J Parenter Enter Nutr. 2020;44:589-98.

24. Davies ML, Chapple LS, Chapman MJ, Moran JL, Peake SL. Protein delivery and clinical outcomes in the critically ill: a systematic review and meta-analysis. Crit Care Resusc. 2017;19:117-27.

25. Blaser AR, Starkopf J, Kirsimagi U, Deane AM. Definition, prevalence, and outcome of feeding intolerance in intensive care: a systematic review and meta-analysis. Acta Anaesthesiol Scand. 2014;58:914-22.

26. Kiss CM, Byham-Gray L, Denmark R, Loetscher R, Brody RA. The impact of implementation of a nutrition support algorithm on nutrition care outcomes in an intensive care unit. Nutr Clin Pract. 2012;27:793-801.

27. Rahman A, Hasan RM, Agarwala R, Martin C, Day AG, Heyland DK. Identifying critically-ill patients who will benefit most from nutritional therapy: further validation of the "modified NUTRIC" nutritional risk assessment tool. Clin Nutr. 2016;35:158-62.

28. Blackburn GL, Bistrian BR, Maini BS, Schlamm HT, Smith MF. Nutritional and metabolic assessment of the hospitalized patient. JPEN J Parenter Enter Nutr. 1977;1:11-22.

29. Looijaard W, Denneman N, Broens B, Girbes ARJ, Weijs PJM, Oudemans-van Straaten HM. Achieving protein targets without energy overfeeding in critically ill patients: a prospective feasibility study. Clin Nutr. 2019;38:2623-2631. https://doi. org/10.1016/j.clnu.2018.11.012.

30. van Zanten ARH, Petit L, De Waele J, Kieft H, de Wilde J, van Horssen P, et al. Very high intact-protein formula successfully provides protein intake according to nutritional recommendations in overweight critically ill patients: a double-blind randomized trial. Crit Care. 2018;22:156.

31. Rice TW, Files DC, Morris PE, Bernard AC, Ziegler TR, Drover JW, et al. Dietary management of blood glucose in medical critically ill overweight and obese patients: an open-label randomized trial. JPEN J Parenter Enter Nutr. 2019;43:471-80.

32. Tang JE, Moore DR, Kujbida GW, Tarnopolsky MA, Phillips SM. Ingestion of whey hydrolysate, casein, or soy protein isolate: effects on mixed muscle protein synthesis at rest and following resistance exercise in young men. J Appl Physiol. 2009;107:987-92.

33. Marshall K. Therapeutic applications of whey protein. Altern Med Rev. 2004;9:136-56.

34. McGregor RA, Poppitt SD. Milk protein for improved metabolic health: a review of the evidence. Nutr Metab. 2013;10:46.

35. Liebau F, Sundstrom M, van Loon LJ, Wernerman J, Rooyackers O. Short-term amino acid infusion improves protein balance in critically ill patients. Crit Care. 2015;19:106.

36. Hoffman JR, Falvo MJ. Protein-which is best?. J Sports Sci Med. 2004;3:118-30.

37. Mathai JK, Liu Y, Stein HH. Values for digestible indispensable amino acid scores (DIAAS) for some dairy and plant proteins may better describe protein quality than values calculated using the concept for protein digestibility-corrected amino acid scores (PDCAAS). Br J Nutr. 2017;117:490-9. 
38. Hoffer LJ, Bistrian BR. Appropriate protein provision in critical illness: a systematic and narrative review. Am J Clin Nutr. 2012;96:591-600.

39. Guadagni M, Biolo G. Effects of inflammation and/or inactivity on the need for dietary protein. Curr Opin Clin Nutr Metab Care. 2009;12:617-22.

40. Leblanc M, Garred LJ, Cardinal J, Pichette V, Nolin L, Ouimet D, et al. Catabolism in critical illness: estimation from urea nitrogen appearance and creatinine production during continuous renal replacement therapy. Am J Kidney Dis. 1998;32:444-53.

41. Suzuki G, Ichibayashi R, Yamamoto S, Serizawa H, Nakamichi Y, Watanabe M, et al. Effect of high-protein nutrition in critically ill patients: a retrospective cohort study. Clin Nutr ESPEN. 2020;38:111-7.

42. Waterlow JC. Whole-body protein turnover in humans-past, present, and future. Annu Rev Nutr. 1995;15:57-92.

43. Mitsiopoulos N, Baumgartner RN, Heymsfield SB, Lyons W, Gallagher D, Ross R. Cadaver validation of skeletal muscle measurement by magnetic resonance imaging and computerized tomography. J Appl Physiol. 1998;85:115-22.

44. Mourtzakis M, Prado CM, Lieffers JR, Reiman T, McCargar LJ, Baracos VE. A practical and precise approach to quantification of body composition in cancer patients using computed tomography images acquired during routine care. Appl Physiol Nutr Metab. 2008;33:997-1006.

45. Dickerson RN. Using nitrogen balance in clinical practice. Hospital Pharm. 2005;40:1081-7.

46. Wernerman J, Morris CR, Paddon-Jones D, Sarav M. Assessment of protein turnover in health and disease. Nutr Clin Pract. 2017;32:15s-20s.

47. Elango R, Humayun MA, Ball RO, Pencharz PB. Evidence that protein requirements have been significantly underestimated. Curr Opin Clin Nutr Metab Care. 2010;13:52-7.

48. Rooyackers O, Kouchek-Zadeh R, Tjader I, Norberg A, Klaude M, Wernerman J. Whole body protein turnover in critically ill patients with multiple organ failure. Clin Nutr. 2015;34:95-100.

49. Kreymann G, DeLegge MH, Luft G, Hise ME, Zaloga GP. The ratio of energy expenditure to nitrogen loss in diverse patient groups-a systematic review. Clin Nutr. 2012;31:168-75

50. Kreymann KG. Protein in der ernährung kritisch kranker patienten. Aktuelle Ernährungsmedizin. 2019;44:269-84.

\section{ACKNOWLEDGEMENTS}

We thank Dr. Atanas Todorov for his statistical support. Critically ill patients are at the highest risk for over-and underfeeding with concurrent muscle breakdown because targeted protein requirements cannot be met in many cases for various reasons. Adequate nutrition is crucial and impacts morbidity and mortality, especially in these patients. The present feasibility study investigated an enteral formula with a high protein-to-energy ratio (Fresubin ${ }^{\circledR}$ Intensive, Fresenius Kabi, Bad Homburg, Germany) which was developed to meet the increased protein requirements of critically ill patients while avoiding energy overfeeding. Study results show that this enteral formula was well tolerated and that due to the high protein-to-energy ratio protein targets could be reached fast.

\section{AUTHOR CONTRIBUTIONS}

Study concept and design: AH, CK, MS, FT-J. Acquisition of data: LG, JH, KL, JS, FT-J, DT, SZ. Analysis and interpretation of data: AH, SR, MS, FT-J. Drafting of the manuscript: AH, MS, FT-J. Critical revision of the manuscript for important intellectual content: all declared authors. Statistical analysis: FT-J. Obtained funding: AH, MS, FT-J. Administrative, technical, or material support: CK, DT. Study supervision: MS.

\section{FUNDING}

Fresenius Kabi, Bad Homburg, Germany contributed to the expenditures of the study by providing the HP:E formula (Fresubin ${ }^{\circledR}$ Intensive, Fresenius Kabi, Bad Homburg, Germany). Open Access funding provided by Universität Basel (Universitätsbibliothek Basel).

\section{ETHICAL APPROVAL AND CONSENT TO PARTICIPATE}

The study was conducted in Switzerland. The study protocol was approved by the local ethical committee and conducted in accordance with Directive 2001/20/EC, as well as Good Clinical Practices (I.C.H. version 4 of May 1, 1996, and Decision of November 24, 2006) and the declaration of Helsinki. Patients were included from May 20, 2016, to January 24, 2017.

\section{CONSENT FOR PUBLICATION}

Written/oral consent for publication was obtained from all study participants.

\section{COMPETING INTERESTS}

MS has received speaker honoraria from Fresenius Kabi, Switzerland. All contributing authors have not had any financial interest related to the study subject and report no conflicts of interest. This investigator-initiated study was funded by Fresenius-Kabi, Bad Homburg, Germany. The funder requested to start with a tolerability trial of 20 patients before further recruiting for the double-blind, randomized controlled clinical trial for comparison of the high protein enteral formula with a standard product on total calorie and protein intake. The funder was not involved in the study design otherwise, data collection, data analysis, and interpretation, writing of the manuscript, or the decision to submit the manuscript for publication. The manuscript was sent to Fresenius-Kabi before publication to determine whether it contained any confidential information or know-how. The authors take full responsibility for the content, completeness, correctness, and accuracy of the manuscript.

\section{ADDITIONAL INFORMATION}

Correspondence and requests for materials should be addressed to A.H.

Reprints and permission information is available at http://www.nature.com/ reprints

Publisher's note Springer Nature remains neutral with regard to jurisdictional claims in published maps and institutional affiliations.

\begin{abstract}
Open Access This article is licensed under a Creative Commons Attribution 4.0 International License, which permits use, sharing, adaptation, distribution and reproduction in any medium or format, as long as you give appropriate credit to the original author(s) and the source, provide a link to the Creative Commons license, and indicate if changes were made. The images or other third party material in this article are included in the article's Creative Commons license, unless indicated otherwise in a credit line to the material. If material is not included in the article's Creative Commons license and your intended use is not permitted by statutory regulation or exceeds the permitted use, you will need to obtain permission directly from the copyright holder. To view a copy of this license, visit http://creativecommons. org/licenses/by/4.0/.
\end{abstract}

cc The Author(s) 2021 